Gediminas Vitkus*, ed.

Lithuanian Military Academy

Institute of International Relations and Political Science of the University of Vilnius

Virgilijus Pugačiauskas*, ed.

Lithuanian Military Academy

\title{
Paradoxes of Belarus: \\ Regional Security with \\ a Transformation in Limbo
}

This is the summary of results from a full-scale research project, which has been carried out by the Strategic Research Center during the year 2003. The main objective of this project was to provide the general public with a deep analysis of the different aspects of Belarus realities and policies in the context of Baltic regional and European security. The research project was implemented by an international research team. Analysis of the Belarus political system was done by Virgilijus Pugačiauskas (Lithuania). The security sector of the Republic of Belarus was covered by Vyachalau Paznyak (Belarus). Analysis of the economic situation was done by Valery Dashkevich (Belarus). Ecological threats originating from Belarus were precisely explored by Eleonora Gvozdeva (Belarus). Sander Huisman (the Netherlands) analysed Belarus realities in the context of the EU's new security and neighbourhood policies. And finally, the general assessment of Belarus as a regional security factor was completed by Gediminas Vitkus (Lithuania). The project came to an end at the beginning of 2004 with the follow-up publication in Lithuanian**. In order to make the results of this project more known to the wider public, we are reprinting the comprehensive English summary of that publication.

\section{Introduction}

The subject of this collective study is Lithuania's closest neighbour - Belarus. A comprehensive picture of the current situation and developmental prospects of the Republic of Belarus are presented here. An effort is also made to create favourable conditions for the most thorough assessment to date of Belarus as a security factor for Lithuania, Poland and the other Baltic countries. Moreover, inasmuch as almost the entire Baltic region is becoming a component part of the European Union, one cannot fail to note that Belarus is also becoming a factor that influences the security of the European Union as a whole.

\footnotetext{
* Prof., dr. Gediminas Vitkus - Head of the Political Science Department of the Lithuanian Military Academy, Associate Professor of Institute of International Relations and Political Science of the University of Vilnius. Address: Šilo 5a, LT-10322 Vilnius, Lithuania tel. +3705-2103569, e-mail: gediminas.vitkus@tspmi.vu.lt

* Doc. dr. Virgilijus Pugačiauskas - Associated professor of the Political Science Department of the Lithuanian Military Academy. Address: Šilo 5a, LT-2055 Vilnius, Lithuania tel. +3705-2127970, e-mail: v.pugaciauskas@1ka.It

** Original title of the book in Lithuanian: Vitkus G., Pugačiauskas V., sudar., Baltarusijos paradoksai: istrigusi tranformacija ir regioninis saugumas, Vilnius: Lietuvos karo akademija, 2004.
} 
Of course another question is for whom, specifically, and how and to what degree this Belarusian factor is important. Paradoxical as it may seem, for example, an acquaintance with literature on the security problems of the Baltic region, which is geographically so close to Belarus, or even of the three Baltic States or, especially, of all of Europe easily reveals that the Belarusian factor is either almost completely ignored by everyone or reduced to the Russian factor. At best, we encounter only brief "marginal" comments or exhortations driven by scholarly conscientiousness not to forget this additional factor.

This situation is easy to explain. It is entirely natural that Belarus disappears from the field of interest of analysts of the European and Baltic security space, primarily because of her own consciously chosen alliance with Russia and identification with the latter's interests. Therefore, even though the leadership of Belarus sometimes stood out during the past decade, before NATO expansion into this region and in response to the prejudice of its electorate against such expansion, by resorting more than once to much harsher and at times even hysterical rhetoric against the entire democratic West, these efforts were little noticed in the rest of the world and inadequately assessed, even in Moscow. According to Clelia Rontoyanni, an analyst of Belarusian foreign policy, one may boldly assert that "to the extent that Belarus has an international role, it has been primarily as Russia's closest and most reliable ally." From this viewpoint, when analysing the security problems of the Baltic region or, especially, of Europe, "not forgetting" Belarus and giving her special attention would be incorrect. An analysis of a security problem that is carried out on a systemic level should not encompass all security factors without exception but should concentrate on the essential structure that defines the existing order - in this instance, the intersection of Baltic and Russian security interests.

On the other hand, this does not mean that in principle a more thorough analysis of all aspects of a security problem no longer has any meaning. Barry Buzan, a British political scientist and authority on security studies, points out that an excessive need to understand the whole before studying an individual phenomenon can create a situation in which "such a tall order threatens to make the study of security unrealistic." Therefore, according to this analyst, in order to enrich the content of security studies, it is necessary consciously to find a hierarchy of analytical levels within the international system, and "each of these levels must identify the durable, significant and substantially self-contained features of a security problem." On the basis of this premise, Buzan proposes to conduct security analysis not only on a national or systemic level but also on a middle or regional level, for although this level is often ignored, in truth it mediates in the interaction between separate states on the one hand and within the entire international system on the other. Also, as long as this level has not been properly studied, neither the status of individual states in regard to one another nor the nature of relations between the great powers and local states can be properly and completely understood.

Bearing this worthwhile idea in mind, let us attempt once more to look at the relationship between the security of states in the Baltic region and Belarus. We think that even without Buzan's suggestions, it is immediately obvious that eliminating or reducing the role of Belarus in an analysis of Baltic security, rather impoverishes the expected results from these studies. If we evaluate the Baltic region as a security 
complex, Belarus does not become a secondary factor influencing regional security. In regard to regional security, perhaps Sweden, Finland, or Estonia could be dissociated from this factor, but even this possibility is inevitably altered by the expansion of the European Union. For Lithuania or Poland, in contrast, countries whose borders with Belarus are hundreds of kilometres long, a posture of dissociation would show a total misunderstanding of the situation even without their having joined the European Union. For these states, the existence of an independent Belarus is not only an important factor of geopolitical stability but is also almost in the interest of their national security because, after all, the territory of Belarus physically separates them from Russia. Therefore, regardless of the political attitudes held by either side, it is evident that Belarus was, is, and will remain not only an immediate neighbour of the states of the Baltic region, but also an organic component part of the security complex of this region with all of the problems and consequences that follow from this fact.

Of course, the editors and authors of this monograph did not forget that the regional security problems generated by the processes existing in and around Belarus are unavoidably part of a broader context and become one of the vectors in a process taking place on a larger scale. Nevertheless, this time the analysts have not set their sights on a structure that determines an international order based on principle but rather on the nuances of that order - in other words, Belarusian realities, the specific characteristics of Belarus, and the regional security problems that follow from them. At any rate, even the smaller regional states are not the mere puppets of forces acting on a systemic level. They have a very limited but nevertheless genuine freedom to manoeuvre. And, as we know, Belarus has used this freedom in a very distinctive way. Instead of following the example of her neighbours, this country has chosen a completely different way of development and has stubbornly kept to it for an entire decade already. Because there is no longer any firm basis for believing that this Belarusian paradox will soon cease to exist, we think that the time is ripe to take a closer look at this country, at her political and economic system, and to try to determine where the reasons for her relative stability lie and, most importantly, what her potential is for change in one direction or another and how that could affect the security of neighbouring countries and the entire region.

What happened to Belarus in the early 1990s may have seemed to many people like a strange prank of history. Indeed, history does sometimes play the most diverse pranks not only on individual persons but also on entire nations. The prank that history played on Belarus was that she was turned into a sovereign state against the will of most of her own population. When the Soviet Union fell apart in 1991, nothing else remained for Belarus but to become a sovereign independent state, even though her political elite of that time had not, up until then, nurtured any plans for an independent national existence.

On the one hand, in the history of the world this is not the first instance in which circumstances have created a state before the formation of a people who seek national independence. In essence, there is nothing wrong with this situation. States may appear, and afterwards their governments may themselves "create" or "finish creating" a nation, a civil society, institutions, etc. In part, this is an impersonal process. To tell the truth, a similar evolution was also expected in the Belarusian case. If external circumstances forced this country to become an independent state, it now 
seemed to many people that she would further be forced to follow the example of her neighbours - to begin creating a democratic state, to undertake market economy reforms, to develop political and economic ties with Europe and the world, etc.

However, as we know, these predictions and expectations have not been fulfilled. In those instances in which the nation does not create the state but the state creates the nation "from above," incidental factors become especially important particularly the specific configuration of political forces or even the values and choices of the personalities that rise to the top of the government. Just as the governments and leaders of states can encourage the formation of a nation, they can also succeed in essentially deforming them and promoting other values, other interests.

As we know, that is what happened in Belarus. Belarusian voters, who before the collapse of the Soviet Union were known for their conservatism and loyalty to the existing order, and who in 1992-1993 painfully experienced the first hardships of reform, decided not to take any more risks and in the next presidential election in 1994 supported a politician who did not hesitate to promise, at least in part, to restore this former order, to preserve earlier social and economic safeguards.

We now understand that what Alyaksandr Lukashenko proposed was in essence to restore the old Soviet system. Most of the people of Belarus liked this proposal to such a degree that since that time voter support for this politician has not waned (or, as befits the Soviet scheme of things, was not allowed to wane). With a landslide vote they supported Lukashenko in the 1996 referendum on constitutional amendments that greatly increased the powers of the president. They did the same thing again in the next presidential election in 2001. Lukashenko now has the official right to remain in office until 2006, and he is already openly considering the prospect of running for a third term even though the constitution does not provide for such a possibility. However, the obedient electorate could, in one more referendum, again easily improve the constitution.

Thus, in the ten years since Lukashenko came to office, there is a sound basis for saying that in a broad sense, he has kept his promise. Those Belarusians who in spite of everything wanted to continue living in the Soviet Union at least in part have got their wish. This fact is attested by the results of this study. Once again, we have an obvious opportunity to be convinced that the main result of rule by Lukashenko is none other than the Restoration of the Soviet system.

However, at the same time one ought not to forget that a Restoration, wherever it may occur, never completely recreates the original. In a picture, alongside the work of the artist, the restorer always leaves his own vision and thus distorts the original. In politics, likewise, Restored Systems cannot totally reproduce the characteristics of their predecessors. For this reason, they either are condemned to collapse once again or must inevitably be reformed in response to changed times. The best example of such a political Restoration is France under renewed Bourbon rule following the Congress of Vienna. As we well know, this political system survived for only fifteen years. Logically, therefore, a similar fate should await Belarus, although clearly one can never know what direction a specific historical process will take.

Obviously, this study did not undertake the impossible goal of answering the question of what fate awaits the current regime in Belarus. Making predictions is a thankless activity. Let us remember how a relatively small number of analysts succes- 
sfully foresaw the collapse of the Soviet Union. We believe that the same imperative of the power of accident also applies in the case of Belarus. It is natural, therefore, that our analysts mainly focused their attention not on formulating speculative prognoses, but on describing and analysing the contemporary Republic of Belarus. When we in turn know this, we acquire a much more solid basis both for assessing Belarus as a factor in regional security and for recommending the policy to be followed in regard to this country. Our authors' approach is reflected in the structure of this study.

The first part of this book examines the characteristics of the Belarusian political system and, most importantly, the problems that arise because of the entrenchment of an authoritarian regime. The second part separately analyses the controversial development of the Belarusian security sector. The third part exhaustively describes the characteristics of the Belarusian model of economic development and the problems that arise because of stalled economic liberalization. The fourth part of this book spells out the scale of the ecological threat that has arisen because of unresolved political, economic, and social problems and that is already becoming perhaps the most serious problem not only in Belarus, but also in the entire region. Finally, in view of the recent expansion that makes Belarus an immediate neighbour of the European Union, the fifth part of this book strives to look at Belarus not only as a factor that influences neighbouring states in the region but also as a factor in the policy of the entire EU, thereby considering the prospects for a further joint EU position. At the end of this book the reader will find a summary of all of the results from this study.

\section{Political System}

This part of the monograph deals with the review of the main political and legal institutions of the state of Belarus, the ways they function, their interrelations, level of dependency and mechanisms and connections with the society on the level of both the Constitution and political practice. Attention is also focused on how the above mentioned institutions form and support the state ideology that according to its authors should become the main idea guiding the sequential progress of the Belarusian state, and correspondingly should assist the state institutions to execute their functions.

It is useful to bear in mind, when speaking about authoritarian regimes and specifically relating to the president and his surrounding institutions, the division of the functions between the government and the parliament and their interrelations. Usually such regimes do not tolerate the principle of sharing power that is essential to democracy, although modern or new authoritarianism is a little bit more "advanced" in this sphere. Formally, they do not separate themselves from this principle but it is totally ignored in political practice. Belarus is an especially vivid example of this point of view. That is why in order to understand how the political system of this state functions, it is necessary not to rely solely upon the analysis of constitutional norms, but to employ the metaphor of the "Power Vertical" that is currently very popular among analysts and reviewers. Evaluating this concept, it is very important to emphasise that the principle of the Vertical contradicts and finally changes the well-known 
principle of "checks and balances", to be more precise - it fully eliminates it from the interrelations of the institutions.

In the case of Belarus, the Power Vertical can be determined as the hierarchical system that guarantees the direct subordination and dependency of all levels of state institutions upon the president and his administration. The highest and primary person of the Power Vertical is the president for whom the Constitution guarantees the post of the Head of State and the weighty positions are guaranteed by the fact that he is elected in direct public elections. The first article of the Constitution of the Republic of Belarus that deals with the general multifunctional parameters of the president as the Head of State reveals that the president has a "strong" role in the political process. The president is not only the embodiment of the nation's unity but fulfils the functions of guarantor of the constitution, human freedoms and rights; he guarantees realization of home and foreign policy directions and represents the state abroad, as is common practice for the presidential regime in a democratic state.

The Vertical is further revealed via involvement of the representatives of the president in the composition of the government and, more interestingly, of the parliament. The work of the government is headed not only by the Prime Minister together with ministers but also by a so-called permanent structure - the Presidium of the Council of the Ministers. This leading institution consists of the Prime Minister and his deputies, the Head of the Administration of the President, the chairperson of the State Control Committee, chairperson of the National Bank board and three main ministers - of economy, of finance and of foreign affairs. It is obvious that the main duty of the president's authorized person is to observe how the policy of the Head of State is implemented. In such a way, the president eliminates even the smallest theoretical possibility of the government to dispose at least minimum independence.

We see an analogous situation with the parliament, although the independence of this institution should not be questioned. Including the Upper parliament chamber - the Council of the Republic - into the hierarchical system does not in practice cause major problems for the president. Alyaksandr Voitovich, i.e. one of the deputies appointed by the president, became the Chairperson of the Council of the Republic. The decision of the president in 2003 to dismiss the speaker of the Upper Chamber by revoking his mandate, to organize an extraordinary session and legally and quickly to appoint former Prime Minister Genadij Novickij as the new Head proves that the application of the "vertical" principle gives "wonderful" results in the case of the parliament. The public confession of the latter: "I am not a politician, I am manager" only further illustrates how coordinated the mechanism of the Vertical functions.

There are no problems with the Lower chamber of the National Assembly. As the result of the president's persistent "work", the chairperson of the Chamber of Representatives, Vadim Popov, together with a group of six deputies are the official representatives of the president in the parliament. This group of deputies has received the task "to clarify and to inform operatively the Head of State about the most acute problems of legislature and everyday problems of the parliament members".

So, the Power Vertical can be identified as one of the most important means enabling the President to concentrate significant personal power. But the President is trying to mask this obvious truth, by making statements in political rhetoric about the 
need to develop closer mutual collaboration among governmental institutions. At the same time, concrete steps are undertaken in order to legitimize the Vertical by juridical documents. The opposition of the parliament to the president is almost impossible because the next step of the president can be easily foreseen - extraordinary elections of the parliament.

But this analysis of the Vertical system in Belarusian political institutions would not be complete without mentioning the problems of state ideology. Rare is the political regime that, regardless of how repressive it is, can be based only on power of institutional organizations and power structures. Both democracies and dictatorships with pleasure appeal to the support of the ideologies that consolidate society. Belarus is not an exception in this respect. And oddly, it is here that we can find the Achilles' heel of Belarus' Power Vertical. Despite all the attempts of the power institutions, ideology was and still is the weakest link of the whole system.

It is known that the idea of building communism has disappeared together with the Soviet Union, and the Belarusian political elite who came to the helm of the independent state failed to propose new ideas that were understandable and acceptable to the society. On the other hand, the liberal Belarusian political oppositionthe Belarusian People's Front - failed to overcome that challenge as well. It was based on a nationalist ideology but failed to mobilize the Belarusian nation and to ensure sufficient support from the electorate to come to power, as was the case of the analogical structures in Lithuania, Latvia and Estonia.

The history of Belarus was developing in such a way that today it is difficult to speak about the traditions of the state and national identity that would be the supporting point and condition for the further successful development process of the nation towards democracy. Such opinions are often expressed in the various research papers that analyse the problem of the Belarusian national identity and look for the reasons for the failure of democratic reforms. That is why there are no grounds to speak about the strong position of a Belarusian national state idea. On the contrary-it can be seen as weak and rudimentary.

Thus we can state that Belarus demonstrates a double weakness of the state idea - on both the national and ideological levels. During the first years of Lukashenko's rule, the state institutions tried to compensate for the state's weakness of ideas, but at that very time the president understood the necessity to dispose of an idea or ideas able to attract the society because the cult of the leader alone cannot guarantee the completeness of the power vertical. It was not by chance that Lukashenko finally initiated a public "debate" about the necessity of having such a conceptual ideologyand openly set the goal -in order to provide the ruling regime with the an additional dose of legitimacy and to give back to the Belarusian nation the socialist "illusions" that were lost during "perestroika".

Because the ideology of Belarus was built from the top down, the "product" is artificial, a condition which prevails in this complicated process even to the present day. It can be stated that only since 2003 has the process accelerated a lot and given more concrete results due to the serious attention of the president to this issue. In other words, from that moment the creation of ideology became one of the highest priority tasks on the agenda of the president. But first let's have a look at the source of this process, which started during the first years of Lukashenko's presidency. 
The first serious attempt to create and popularise an independent state ideology was conducted by the scientific personnel of the Social and Political Research Institute. Two years' effort yielded negligible results because a social ideal able to fill the ideological vacuum in the society just was not found and the main customer was not satisfied with the proposed forms. Another direction of the activities came from multiple discussions in the top power echelons. Meetings with the academic society were not useful either.

More achievements were accomplished in the easiest sphere, namely, setting up the ideological institutions and positions. First of all, the Department of Ideology appeared in the Presidential administration's institutional structure. Corresponding positions were set up in the lower level power institutions: the boards of the district executive committees and in the analogous sections of the cities, namely -information departments. These proved insufficient, and then the ideological organizational development stepped over the frames of the governmental institutions - step by step, staff positions of the "ideological employee" were introduced in various establishments, organizations and enterprises. So, the institutional contours of the ideological Vertical appeared in the state.

We can make the following observations regarding this initial, quite prolonged stage of organized ideology creation: firstly, the power institutions are oriented to the solution of the ideology creation problem; secondly, the obvious disproportion between the institutional structure of the ideological Vertical and the processes of creating a an ideological concept became vivid when the latter lags far behind. In other words, the institutions serving the ideology are essentially created, but the ideology, as a set of concrete and fundamental ideas, is still at the initial stage of its formation. Thus, the conclusion is very simple - the state institutions are not able to propose clear and attractive ideology to the society.

As was mentioned, since 2003 we can notice the activation of a process that can be related to the concrete event - the seminar for the Heads of the state institutions to discuss the issues of how to perfect the ideology. The President announced the obligatory performance of the ideological Vertical on all levels of state governance, i.e. by territorial and branch principles. Thus, we learn not only how the organizational structure of the Vertical must operate but also that in reality it has not yet developed its total character. In order to accelerate that process Lukashenko directed the extensive formation of ideological units in the "working collectives" and the introduction of a permanent deputy to the Head of any enterprise or organization employing over 150 employees, who would be responsible for ideological work. What is interesting is the stressing of this principle as applied to all organizations, irrespective of their purpose or ownership form.

So, starting with the President, who obviously is the guarantor of ideological formation, development and implementation, other institutions are also oriented towards caring for this ideology and strengthening it. The President, as the official of the state who is mostly interested in the dynamic and content of this process, was obviously not satisfied with the work of his subordinates that dragged on too long without concrete results. This was proven by the public critics of the institutions (the President's administration and the Governing academy) responsible for ideological activities, resignations of the officials and as was usual in such cases - categorical and ultimate orders from the Head of State. 
The second major direction of the activities is oriented towards education. Starting with this school year a programme of ideological lectures "The basics of the Belarus' state ideology" is being introduced in the country's higher education institutions. The programme was created by the employees of the Department of Ideology of the Management Academy. The methodological instructions indicate the goal - to form important ideas for the students' values, beliefs and aspirations that are of vital importance to the Belarusian society.

What are the ideas proposed by Lukashenko? Despite long-term efforts by the authorities and scientific personnel, a comprehensive, and more importantly clear, ideological concept was not created; according to the opinion of many experts it is only a collection of separate theses. Following are the main ones: communitarism and collectivism as counterbalance for the Western individualism, internationalism, the important role of the state especially in the social sphere, and lately more of an emphasis on the faith, demonstrating the support of the ruling regime by the Orthodox Church.

On the basis of the aforementioned themes, we can state that the organizing ideology is closely connected and related to Lukashenka's authoritarian institutional power structures - it is created, propagated and strengthened in order to solidify additional support for the legitimacy of the regime. On the other hand, we can easily identify the weaknesses of the created ideology, the main signs of which are the following: it lacks theoretical completeness, it is artificial (inspired by the initiative of political leadership), institutions choke the ideas themselves, and finally, due to its brief existence, it does not have deep roots in the society. Society's support of the ideas cannot be attributed to the fact that they are attractive, needed or understandable to the society, but rather because such support is demanded by the authorities. If suddenly orders to support the ideology were revoked, the apparent needs of the society would disappear as well. In such a situation, this component of state legitimacy is strongly dependent on changes of the political leadership.

Summarizing the above, we should state that Lukashenka's personal power dictatorship has been created, it is functioning and at the same time its stability is constantly ensured by constitutional means; to be more precise, the imperfection of the constitutional mechanisms provides the president with unlimited freedom of manipulation, directed to preserve power in his hands for as long as possible. That is why the main source of this dangerous situation is the significant concentration of power when everything in the state depends upon one person whose political actions are almost impossible to foresee. Finally, the political system and organizing ideology discussed above are also the result of one politician's purposeful initiative and activities that are thrust on the society, though with the consent of the majority of this society. Thus, there is sufficient evidence that Belarus is a weak state due to its internal deficiencies and that it remains a potential source of instability and danger for its nearest neighbours and for the entire surrounding region. 


\section{Security Sector}

Like many other post-communist countries in transition, Belarus had to reduce and restructure its military and security establishments, which were inherited from the Soviet Union. It also had to deal with the Communist strategic culture. The difference, however, is that the legacy of the old mentality and attitudes in this country have been particularly firmly embedded. There are also signs of their revival. Although it would be an overstatement to say that the situation has come full circle, many aspects of the Soviet past have been restored, although under the guise of a sovereign state. Belarusian defense and security structures are comprised of the top political leadership, the so-called "force bloc" - Defense Ministry, Interior Ministry, State Security Committee (KGB), Ministry for Emergency Situations, Border Troops Committee, State Customs Committee, Procurator's Office, as well as a number of interdepartmental agencies, such as the Commission on Export Controls and the Commission on Economic Security. The central role among them, de jure and de facto, belongs to the President and some groups directly subordinated to him, especially the National Center for Draft Law-Making. The latter's activities are not envisaged by the Constitution. The Presidential Administration (President's Office) is also taking an active part in the shaping of state security policies by preparing decisions concerning cadre appointments, implementing interdepartmental coordination and supervising governmental policies on major domestic and foreign issues.

The normative basis for SSR in Belarus is the new National Security Concept (NSC), adopted in July of 2001 to replace the previous one that had been in force since 1995. The new NSC lists one of the main national security functions as "control over the activities of state organs, organizations, including public associations, as well as citizens, involved in the sphere of national security, and informing citizens on issues of ensuring national security." According to the document, the system of ensuring national security is a "complex of bodies ensuring national security, which are united by the objectives and tasks of protecting the vital interests of individuals, society and the state and which are performing coordinated activities within the framework of law." This system includes state organs, organizations, public associations and citizens. It is directed by the President through the Security Council and the Council of Ministers.

The package of military laws adopted in 2000-2003 radically consolidates the controlling functions with the President. For example, according to the Law on the Armed Forces adopted in July of 2002, control over the armed forces is executed by the President, the Council of Ministers, as well as other state organs within the limits of their competence. This new version of the law does not mention the parliament, which was included in the draft text.

The "gravity center" in the Belarusian law- and decision-making mechanism is the National Center for Draft Law-Making under the President, and the Council of Ministers, along with the subordinate ministries. However, the role of the parliament is secondary. The latter lacks sufficient financing, staff and expertise to perform fullfledged law-making functions concerning national security.

The process of creating a comprehensive system of ensuring internal and ex- 
ternal security, which aims to consolidate the existing political regime in Belarus, is paralleled with an unprecedented state-centric securitization across the security sectors - military, political, economic, and societal. The activities of the opposition political parties, civil society actors, NGO's, human rights groups, independent trade unions, as well as foreign foundations and even education projects are seen by the propaganda apparatus as a real threat to the stability of the Lukashenka regime. The same applies to the external milieu. But the logical result of it, however paradoxical it may seem, is that the domestic support to the regime is dramatically waning, with the first-ever majority opposing the continuation of Lukashenka's term in office.

The year 2003 has become another important mark in the formulation of the military-political strategy of the Belarusian state. According to the country's political leadership, NATO enlargement to the East and the possibility of using military force without a UN mandate have seriously complicated the military-political positions of Belarus. Minsk regards the possibility of the deployment of US military bases in Poland and other Central European countries as a threat to its national security. In December 2003 the Security Council of Belarus adopted a package of coordinated plans for preparing the state's government, economy, finance, territory and the population for the contingency of a military threat. President Lukashenka signed a special Plan of the Country's Defense during Emergency Periods, which is premised upon a conclusion that the world has come back to the condition when "war and power pressure are real foreign policy instruments," some states are seeking hegemony and a "monopoly on domination," and international law "cannot fully guarantee the protection of state sovereignty and territorial integrity."

Concentration of the country's efforts towards creating an autonomous system of national defense - as if informed by a realist "self-help" principle - may imply a "mission impossible." The security autarchy of Belarus in Europe today seems totally nonsensical for many reasons. First, the country has no resources or any other means required to "go it alone." Second, it is based on the miscalculation, in fact an overstatement, of the military factor and an underestimation, if not a complete disregard, of cooperative security arrangements. Last but not least, there is a misperception of security risks and challenges to Belarus.

Belarus' leadership claims that the country is confronting the "cultural and ideological aggression of the Western world," and "the time, the destiny and the situation have nominated Belarus for a great role as the spiritual leader of the Eastern-Slavic civilization." Fully in line with this view, Belarusian specialists in national security have inferred that "prevention and neutralization of threats to national security in the humanitarian sphere require, first of all, an open declaration of an official state ideology, acceptable for the majority of the population and taking into account cultural and historical traditions of the Belarusian people. Only based on such an ideology is it possible to work out clear criteria for identifying threats to national security, as well as the main priorities and state policy in this sphere."

Belarusian authorities are expanding the veil of secrecy and control over information, which is motivated by political and ideological calculations reminiscent of the Soviet times. As a result, there is a confluence of several tendencies: centralization of the management in the information sphere and its infusion with state ideology; tightening of administrative control over the mass media; and control of the 
production, distribution and consumption of information. This is being done against the backdrop of continued state dominance in political, economic and property relations.

The security sector in Belarus, according to its planners, is nearing completion with the installation of a comprehensive system of control, crowned by the socalled "state ideology." This last element, however, is likely to overload and topple the whole construction. As history shows, an "ideological completeness" of a closed society ends up in the degradation and collapse of the whole system. With today's globalization processes, such a system will stand even fewer chances to sustain itself.

A "single-vector" orientation of Belarus foreign and security policy toward Russia and its drive to integrate have turned it into a Russian military outpost and a geopolitical simulacrum of a "union state." Belarus has also defended the Collective Security Treaty (CST) from the Western direction. As a result, these geopolitical roles have separated and distanced Belarus from the processes of shaping cooperative security systems in the region as well as in wider Europe.

Belarusian authorities have been enthusiastic about transforming the CST into the Collective Security Treaty Organization (CSTO) and took a very active role in it. President Lukashenka went so far as to declare that he considers the use of national armed forces legitimate in case of aggression not only against Belarus, but also against its allies. Nevertheless, after Russia's rapprochement with the West, Belarus finds itself in a puzzling position. The CSTO has started implementing a plan of cooperation with NATO. So, as a member of the CSTO, Belarus is bound to cooperate with an alliance it has perceived as a military threat. Besides, the main CSTO grouping will be located in Central Asia, which is an indication of the lesser importance of the European theatre for Russia and other CSTO member-states.

The new Russian strategic thinking demonstrates other asymmetries with the Belarusian orthodox approaches. With many reservations, Moscow names NATO and the U.S. as its strategic partners, while Minsk is far away from a similar level of relations.

At the moment, the prospects for Belarus' incorporation in the Russian Federation are very unlikely. At the same time, what used to be called "Russian-Belarusian integration" has gone quite far, especially in the military-strategic area. Although the present stage of integration (political, military, economic, financial, institutional, etc.) has not yet completely deprived Belarus of autonomous decisions and actions, it is already much more constrained than, for example, Ukraine, in making a pro-European strategic choice. This is especially true with regard to European security structures. Also, the decade-long Belarusian integration odyssey has produced in the West a record that will not be easy to change even if a U-turn in relations with the West is attempted in full faith. This untrustworthy image is underpinned by the fact that in the military and security sphere Belarus used to follow the Russian hard line and continues to tread the same path, even after the pilot has changed course.

The true reason behind the unwillingness of the incumbent Belarusian leadership to acknowledge the new security order in Europe and change its policies accordingly may be very simple. It could be not the fear of changes as such, but of losing power as a result of changes. A similar concern may explain Lukashenka's recalcitrance to agree with Russia on further practical steps of "integration."

So, in the case of Belarus there is a combination of domestic and foreign 
"power politics" clearly directed at the continuation of the political regime, which serves as a measure of political efficiency regardless of multiple failures, as judged by either ordinary formal or informal criteria.

\section{Economy}

The Republic of Belarus is the only former socialist country that hasn't accomplished the task of economic liberalization after 11 years of sovereignty. As a result, it now has a unique economic system, halfway between a socialist planned economy and a free market economy.

Rejecting the path of fast market reforms and preferring the policy of slow changes under strict state control, Belarus managed to restore its production volume to the level of the 1990's and to avoid deep social stratification of the people. That success allowed the leadership of Belarus to declare the existence of a specific model of transition to a market economy. This statement requires some explanation.

First, the successes of Belarus may be praised only in comparison with some countries of the CIS, where the reforms were accompanied by an open criminalization of the economy and mass export of assets. The successes of Belarus in comparison with the majority of the Central European countries and the Baltic States are very moderate, and the growth indices are much lower than in Poland, Romania, and Slovenia.

Second, none of the European countries had the level of outside preferences that Belarus had. Thus, during the whole transition period it received, and still is receiving, cheap sources of energy from Russia. Belarus accumulated debts owed to Russia from gas and electricity payments. The majority of these payments were carried out in the form of barter accounts guaranteeing its own enterprises the sales of non-liquid products. In the second half of the 90's such barter payments for gas alone amounted to 400-450 billion USD per year.

Third, the government of Belarus avoided a decrease in the production rate during the initial stage of the transaction period by crediting its large state enterprises while the neighbouring countries were faced with a serious slump in production. This helped the Belarusian enterprises to capture a partial hold over the sales markets of their main competitors' products.

Fourth, by refusing to privatise large enterprises, the government managed to preserve its control over them and thus avoided the extraordinary development of freeing those assets and their exports through the mechanism of a price scissors.

Fifth, the strict state control over the economy helped the Belarusian government to avoid a marked decrease in tax revenues by being able to maintain a high collection rate. This guaranteed financing of the main budget expenses, including education, health care, and social care, thus gaining electoral support in opposing the demands of market reforms.

But at the beginning of this decade it became quite obvious that such economic policy had exhausted itself and the rates of economic development began to slow down.

The most generalised definition of this policy is as a mixture of the primitive natural "keinsianity" in the sphere of the administrative, stimulating the overall internal demand with some elements of the free market in foreign trade. 
To realise this course, the Belarusian government widely used the methods of state regulation of prices and incomes, pursuing the tactics of "the soft budget limitations". It stimulated the economy through Central Bank outlays and budget subsidies; it practiced taxation privileges for great machine-building enterprises and the agricultural sector; and it quoted and licensed export-import transactions for more than 1200 various types of business activities.

Strict state regulation of the economy was one of the main principles of the Belarusian economic model, which has nothing in common with large private business. As a result, the privatization of the state sector was ceased in the initial stages. Moreover, at the end of the 90's the government put into operation the rule of the socalled "golden share," which permitted the authorities to interfere with the activities of any joint stock company if the state possessed at least one share.

Still, the analysis of the government's decisions in recent years doesn't lead to the conclusion that the Belarusian practice of state regulation is systematic in character and possesses its own inner logic and predictability. As a rule, all of the government activity is directed towards regulating the economy irrespective of strategic aims. The latter, formulated in the 5-year programs (the first program covers 19962001, the second -2001-2006), are not obligatory. Their adoption was timed to the election campaigns of Alyaksandr Lukashenko and they were nothing but a collection of populist slogans. For instance, the last program puts forth an objective for the necessity of further developing national programs which increase home product exports, food production, and house building.

Annual macroeconomic forecasts approved by the President and having the character of the mandatory socialist plans are more exact. They include tasks on 16 parameters in total: GDP growth, increase in production and agricultural output, investments, the amount of housing put into service, the real median wages and salaries, inflation, national currency exchange rate, energy conservation and material consumption of GDP. The government submits its reports concerning the fulfilment of the plan to the President once per quarter and this is the efficiency criteria of economic control. That's why all the claims of the government about its adherence to the norms of a market economy confound national and foreign businessmen, so they do not risk investing serious funds into the Belarusian economy.

In spite of the growth of quantitative indices in recent years, the Belarusian economy can't afford to improve its qualitative characteristics. Moreover, this quantitative growth was unstable and has a noticeable tendency of decreasing. This is typified by the production of manufacturing products (the index of 10,3 per cent in 1999 dropped to 4,3 per cent in 2002). Agricultural production, which reached record levels in 2000 due to favourable climatic conditions, also demonstrates minimal growth. The GNP growth index has been unable to achieve 5 percent during the last two years. The index concerning investments was marginally improved, but its increase is connected primarily with the increase of housing construction in the country which is financed mainly from the budget. In 2001-2002 the share of nonproductive investments equalled 60-65 per cent of all investments.

It is expensive for Belarusian enterprises to maintain even a moderate tempo of growth due to the expense of using out-of-date equipment. The number of unprofitable enterprises has recently been increasing, and correspondingly, the mean pro- 
fitability of the economy is steadily decreasing. According to the results of 2002, the number of unprofitable enterprises was 34,9 per cent of the total number, and the mean profitability was 8,7 per cent, i.e. the majority of enterprises are unable to invest in their own development.

Worsening of the financial state of Belarusian enterprises led to problems with the formation and fulfilment of the national budget. The share of state budget profits in relation to GNP decreased from 36,5 per cent in 1999 to 33,9 per cent in 2002 , and the budget expenses decreased from 39,5 per cent to 34,3 per cent. This is mainly due to the tax privileges granted to many manufacturing and agricultural enterprises because of their low solvency. There is also a continuing tendency of growing debts of tax-payers' payments to the budget. According to various estimations, at the beginning of 2003 the total sum of tax privileges and overdue payments was equal to 500-600 million dollars, i.e. about 10-12 per cent of the budget profits or 2,5-3 per cent of GNP.

Inadequate financing of the Belarusian enterprises and the inherent difficulties with the budget revenue will threaten the further increase of real incomes for the people, which is the main argument of the present government in favour of its economic policy. This is due to the fact that up to 70 per cent of the incomes of the citizens are formed from the funds of labour payments (51,8 per cent of all incomes) and social transfers (18,2 per cent).

One should also keep in mind that the official statistics give only approximate data concerning the real incomes of the citizens. It estimates the incomes from entrepreneurial activities as 28 per cent of total earned income. The methods of calculating this index are far from perfect, and the index itself is used to equalize the proportion of the volume of retail sales turnover and the volume of paid off salaries and pensions. In fact, the recognition of incomes from the shadow economy equals 40-50 per cent of GNP according to independent experts' estimates.

Such an active shadow economy is predetermined by a number of specific features of the Belarusian economy. First of all, it is due to the general rejection of private business in the country as official economic policy. It takes a lot of time and money to establish one's own business, to get registered, licensed and so on, and nobody can guarantee its further existence. For example, in the second half of the 90's there were two campaigns in the country to reregister all enterprises and reproduce all documents. The second reason is the high level of taxation, equating to $45-50$ per cent of added value. This is the result of Belarus' dependence on foreign markets. About $2 / 3$ of its GNP is aimed for export, and this simplifies the possibility of creating dealer links, including shadow dealers controlling export/import transactions.

In general, the state of Belarusian foreign trade greatly influences the economy. Having no natural resources of its own and being overloaded by great industrial enterprises, whose products can't be consumed by the home market, the Republic of Belarus is wholly dependent on the health of foreign markets, primarily, the Russian market.

In recent years, the market situation was more or less favourable for Belarus. Excluding the fall of the foreign trade turnover in 1999 due to the consequences of the financial crisis in Russia, Belarusian exports during the last five years were stable at the level of 7-7,5 billion USD. In 2002, it exceeded the level of 8 billion, totalling 8,1 
billion USD. The negative characteristics of Belarusian foreign trade turnover are as follows: imports constantly exceed exports, and as a result Belarus has an annual negative trade balance totalling 1,3 billion dollars, thus creating problems for the cash sector of the economy.

During the period of its national and political sovereignty, the Republic of Belarus failed to solve the problem of maintaining a stable national currency - the Belarusian rouble.

The reasons are as follows: the authorities do not understand completely the nature and the role of the modern monetary system in the economic life of the state because they lack economic literacy. The leadership of Belarus mainly consists of representatives with agricultural and polytechnic education. Secondly, the sluggishness in conducting currency reforms which is connected with the failure to understand the collapse of the former USSR and with the hopes for Russia, viewed as the inheritor of the united currency space as well. The final reason is the sluggishness of the general economic reforms, for which the republic's leadership had to use cash to solve social problems, including outlays for financing the budget deficit and supporting the internal manufacturers.

The impudent behaviour in managing the money circulation in the country led to record increases in prices and the decrease of the national currency exchange rate relative to all other post-socialist countries. During 1992-2002 the overall growth of consumer prices increased 2,7 million times, and the exchange rate of the rouble (including the soviet rouble) decreased by 9,5 million times.

But the main peculiarity in conducting the credit and monetary policy of the transient period was the fact that the high level of inflation and devaluation of the Belarusian rouble continued in the second half of the 90's when all the other countries of the former USSR, the central and south-eastern European countries, had already overcome the consequences of the socialist economic system collapse and managed to stabilise their own financial systems. The Belarusian leadership, in spite of the experiences of other countries and the recommendations of the world finance organisations (World Bank and International Monetary Fund, of which Belarus became a member in 1992), went on with its "soft" monetary policy. Only at the beginning of the $21^{\text {st }}$ century, the authorities undertook some reasonable measures of regulation, including reducing outlays and liquidation of multiple currency rates (official, market, shadow etc.). As a result, the tempo of the price growth decreased.

Now it is quite obvious that the economic policy was failing, causing the rate of economic development to slow down.

Based on available information, we may suppose that the Republic of Belarus, together with the other former republics of the USSR, is trying to catch up to the level of post-industrial development seen in developed countries, but lags behind by 40-50 years. Its main objective as a sovereign state is to reduce this interval by 1,5-2 times during the active life of one generation, that is, every 25 years. In order to solve this task, the rate of its economic development must be twice as high, on average, as in the rest of Europe. For the last 50 years the European economy grew at the average rate of 2 per cent per year. Consequently, in Belarus this index cannot be lower than 4 per cent. It will be very difficult to provide such a tempo for 25 years. Especially if we take into account that nobody currently knows how the world economy will develop in the next 25 years. 
In any case, Belarus now needs structural reforms directed to formation of the market economy institutions which will help to realise the economic interests at all levels of society.

Structural reforms should first of all divide the economic and political functions of the state. State regulation shouldn't be identified with state control. The state should leave the real sector of the economy, in other words, all state enterprises should be privatised. This is a necessary precondition for reforms. And it doesn't matter how to privatise, whether to sell enterprises to foreign investors, or to trust them to the present management following a stock purchase.

The second most important problem is the formation of a developed financial market. It is currently in its infancy, and it needs stable currency and the free circulation of capital to function normally. There are also problems with compiling state budgets with a moderate deficit.

The third group of problems concerns the development of a legislative system and an independent judicial system for the activities of all economic subjects.

The Republic of Belarus was the first among post-soviet states to restore the pre-reform level of production output. But if it is late with structural reforms, there will be serious problems with its political and economic sovereignty. The steps taken towards economic integration with Russia have proven the bankruptcy of "the Belarusian model" of market reforms.

\section{Environment}

After the cold war era, the military threat to peace and national interests were replaced by a range of smaller threats whose effects are serious enough to threaten world stability and peace. Among them, ecological threats - degradation of resources and the environment - are considered to be among the gravest ones. The ecological security in the processes of globalization will be built up with a focus towards the nations' contributions to the degradation of the environment and their roles in protecting the biosphere.

Countries' dependence on ecological processes within their territories has become a burning topic for a European region with new members joining the European Union. The borders of the EU are approaching the states where ecological threats are not always adequately analyzed, detected early or prevented. The significance of many ecological threats on the national security of countries in transition does not correspond to the threat reduction strategies and reactions of these countries. In these countries, degradation of ecosystems has already caused serious losses in the economy and caused people to migrate from ecologically threatened regions.

Challenges to Belarusian ecological security have a potential to become regional ones due to the geographical situation of the country and international value of its natural territories. Regardless of this fact, the weight of national ecological threats in the national security system and their international impact have not been sufficiently analyzed. The main difficulties faced while analyzing ecological threats are due to underdeveloped principles of sustainable resource management and environmental protection. Though some results have been achieved in elaborating the theoretical 
principles of environmental management, mechanisms of prevention and reaction to ecological threats remain embryonic.

This chapter is an attempt to describe the existing threats to the environment in the context of European cooperation for common security. The paper is based on statistical data; ministerial reports; research of scientific institutions and independent international agencies; theses of scientific conferences and international projects.

First of all, the general picture of Belarus' place in Europe, its threats in the field of environment and the country's framework of national ecological security are described. Belarus preserves $65 \%$ of its natural ecosystems, thereby absorbing greenhouse gases, and thus being an oxygen donor for the whole of Europe. All the big rivers of Belarus are trans-boundary and its territory is subjected to transboundary air pollution from other European countries. The main reasons for environmental degradation and ecological threats are rooted in the dominance of economic values of development, old and inadequate industrial and pollution prevention technologies, and absence of ecological values of development. As a result, the growth of economic losses due to air and water pollution has a tendency to grow faster than GDP. Due to the fall in production levels in Belarus, the environment has experienced substantial positive changes, but these improvements have gone unnoticed and will likely disappear in the future.

In Belarusian legislation, the definition of ecological threat is not given due to the lack of assessment methodologies for a spectrum of risks, from ecological threats to the complex system of "nature-society-economy". The Concept of National Security defines "threat to the environment" indirectly through "threat to national security" and "life-important interests in the field of environment." Thus, threat to national ecological security can be described as actions, phenomena or processes (or their combination) keeping a person, society or the state from the realization of their lifeimportant interests in the field of the environment.

Aggravation of destructive processes in the environment of industrial regions, worsening of the quality of the environment, degradation of renewable resources and the risk of techno-catastrophes happening as a result of badly financed declarative ecological programs, may push the Belarusian environment to the threshold of irreversible changes and make further protection activities senseless.

Further in this chapter, the threats to the environment in Belarus emerging from various anthropogenic influences are analyzed. Internal ecological threats are mainly diffuse (water, soil contamination, losses of biodiversity and wetlands) and do not have an acute immediate character, but prevent the country from realizing lifeimportant interests in other spheres of their national security concept. Specific ecological threats to national security emerge from the consequences of the Chernobyl catastrophe.

Soils are the basic component of the biosphere. Soil damage automatically ruins related ecosystems. Losses of soil in the process of erosion, desertification or chemical pollution bring countries to economical defaults, social conflicts and population migrations. The loss of soil fertility due to the above mentioned factors is the main threat to ecological and economic security. The "hot spots" of soil erosion in Belarus are located in Polesie, where soil erosion in some regions reaches $60-70 \%$. 
Chemical pollution of soil took place in the previous years due to excessive and ungrounded use of pesticides. As a result, 150000 ha of soils are hyper limed, 260 000 ha contain $\mathrm{Cu}$ (mobile), and 179000 ha $-\mathrm{Zn}$. The level of soil contamination by heavy metals is above norms in all sample cities. Landscape transformation is another complex ecological threat appearing as a consequence of mineral resource excavation. The landscape transformation of the Sologirsk industrial region as a result of potassium extraction, resulted in the deformation of deep level rocks, higher seismic activity, salination and chlorination of soils and underground waters (5000 ha of agricultural land is occupied by potassium extraction side-products). The ecological threat is spread over an area of $120-130 \mathrm{~km}^{2}$.

Biodiversity plays a crucial role in realizing life-important national interests. Losses of biodiversity cause dysfunctional ecosystems and may lead to ecological catastrophes, changes in climate and landscape transformations. Losses of biodiversity in Belarus are connected mainly with the loss of habitats due to economic activities. For example, the loss of Polesie wetlands has caused a $90 \%$ extinction of Ąńrinåššhąlus šąludicola. In 2001, the Red Book of Belarus comprised 1580 habitats of 77 species of fauna and 777 habitats of 99 species of flora. The protected territories occupy 7,6\% of Belarus. Compared with 1990, the territory of protected lands increased by $32 \%$ while the financial allocations in the Republican budget for their maintenance decreased by $38 \%$. The present concept of biodiversity conservation in Belarus is based on the methodology of the 80's. The forests of Belarus occupy 36,3\% of the territory and play an important role in gas and ground water regulation. Though the forest territories in Belarus have grown, the quality of forests is worsening. Defoliation is twice as severe as that of European forests and the percentage of withered trees has increased by 1.6 times since 2000 . Anthropogenic influence in the form of melioration, chemical pollution through the air and bad management, create a threat to the oldest and most unique European forest, Belovezhskaja puscha.

Wetlands are the key type of ecosystems on our planet; they regulate water and nutrient cycles and absorb greenhouse gases. Losses of wetlands cause climate changes and the degradation of soil, leading to the loss of biodiversity and ecological catastrophes. Polesie wetlands occupy $32 \%$ of Belarus territory and are inhabited by $29 \%$ of the population. It is a highly developed economic region, using soil extensively in agriculture and industry. Additionally, Polesie wetlands play a crucial role in the stabilization of natural processes in Europe and thus should be preserved in their original form. The most valuable of Polesie's 35 landscape types are bogs (14,2\% of the territory), because they absorb 7-15 times more carbon than forests and because Polesie is the habitat for the maximum per cent of populations of some species. The wetlands before melioration (1950) occupied 2939000 ha. Now almost $80 \%$ of these lands are meliorated to various extents (almost $2 \mathrm{mln}$. ha). History has never known another example of such a large scale melioration. Moreover, the melioration was not scientifically grounded and did not take into account any ecological estimates of consequences. It was carried out in violation of the projected construction of artificial water reservoirs for the intake of water from meliorated territories. Melioration of the wetlands caused irreversible changes in ecosystems and hydrological regimes, changed landscapes and caused hyper mineralization of soils, making them infertile and vulnerable to chemical migration into the ground water. About 290 
thousand ha of bogs are classified as degraded. Many of their ecological functions have already ceased. The total negative influence of meliorated wetlands is felt over 3 mln. ha.

Pollution of water resources may constitute a threat to genetic and reproductive health, economic prosperity and social stability. Keeping water quality at a safe level is a nation's duty towards the next generations while the decrease of its quality may cause regional and global conflicts. Belarus is a water-rich country. Its water potential is $57,9 \mathrm{~km}^{3} /$ year of surface water and $15,9 \mathrm{~km}^{3} /$ year of ground water, that is enough for meeting present and future water needs. Water consumption per head remains very high - 240-370 litres daily (in Europe - 120-150 litres daily).

The quality of ground water is the main concern because $95 \%$ of the drinking quality water is extracted from ground sources. Ground water in Belarus is characterised by a high level of Ferro and Manganese and low content of Fluoride. Extensive use of agricultural chemicals has made the level of chlorides 4-6 times above the permitted maximum concentration, sulphates $-2-4$ times above norms, nitrates -6 10 times above norms. The situation is much worse in the territories under the influence of stock-breeding farms. Water extraction points do not meet sanitary requirements. Presently 52 of them significantly influence the water regimes of 48 rivers. $56 \%$ of the plants do not meet the sanitary requirements. In some cities $30 \%-70 \%$ of water samples do not meet the sanitary requirements. Meanwhile, the share of samples with unacceptable epidemiological characteristics is 19\%. The threat to drinking water quality is created by the low quality of worn-out water supply systems in the cities which are under threat of collapse. In rural areas, with a population of 2.8 mln. taking water from wells, the situation is even worse; about $30 \%$ of samples do not meet the microbiological parameters for drinking water and about $50 \%$ - sanitary parameters.

Annually about $25 \mathrm{mln} . \mathrm{m}^{3}$ of inadequately cleaned water is discharged into rivers. The capacity of water treatment plants is bigger than the volume of incoming sludge, but many of them take polluted waters with concentrations of pollutants higher than the permitted level. In many cities, water treatment plants are overloaded and technically inefficient. The main polluters are industrial enterprises and the cities' communal water treatment plants. There is an increasing trend in the amount of water discharged by polluters. For example, since 2000, $50 \%$ of enterprises have increased their discharges, $40 \%$ have kept the same level and only 2 enterprises have decreased their water discharge. $40 \%$ of surface water pollution is accounted for by air pollution. As a result of the worsened self-cleaning capacity of rivers, reduction in water discharges does not result in an improvement of surface water quality. In 1999, only $10 \%$ of Belarusian rivers were classified as relatively clean, $80 \%$ as acceptably polluted and $10 \%$ as polluted.

Accidents at enterprises may cause heavy transboundary pollution and interfere with the security issues of other countries and the common security of entire planetary regions. That is why the responsibility of countries for state-of-the-art environmental performance of their industries is a common security concern. Diffused threats to the environment from emissions and discharges of industrial enterprises seem less acute given the general downfall of Belarusian industry. However, 539 chemical and 400 explosive enterprises carry a threat to the life of ecosystems and 
people due to a $70-80 \%$ deterioration of their basic funds. The operation regime of many of these enterprises has become sporadic, creating a threat of volley (accidental) emissions and discharges.

The threats caused by the Chernobyl catastrophe stray beyond the limits of the frontiers of radioactive polluted territories and define the development of the victimstates. Consequences of the catastrophe are considered to be the main threat to Belarus national security, but it may grow into a regional threat of irreversible degradation of the functional qualities of the biosphere. The Chernobyl catastrophe reminded humankind of the global character of ecological threats, interdependence and the responsibility of countries. It also revealed serious institutional gaps in the common security concept and the protection of the environment. The consequences of the Chernobyl catastrophe affect all life-important interests of national security and thus are considered to cause threats in the political, economic, military, ecological, information, and humanitarian spheres.

As a consequence of the catastrophe, $23 \%$ of the territory of Belarus was contaminated. The contaminated territory was an economically developed part of Belarus: 123 fossil deposits ( 22 of them were closed), the second and third most important industrial centres, $20 \%$ of agricultural land, $20 \%$ of forests. After the catastrophe 135 000 persons were resettled; 415 settlements, 283 industrial entities, 607 schools and kindergartens, and 95 hospitals were liquidated. The percentage of pension aged people in some of the contaminated regions is $70 \%$. The three most contaminated regions "lost" $50 \%$ of their population. Due to "spotty" contamination, about $4 \mathrm{mln}$. Belarusians are exposed to radioactivity. Radioactive elements are present in all components of the ecosystems, including in nutrient cycles, thus creating multiple ways of contamination and interfering with the effective use of natural resources. By the year 2050, the activity of Americium ${ }_{241}$ will double that of Plutonium ${ }_{239,240}$ making the radioactivity of soils 2.4 times higher than the post-catastrophe period. The number of settlements with a high level of contamination will increase. The country lacks the financial and technical means to monitor Americium ${ }_{241}$ or to develop any feasible contingency programs, which may undermine its ability to adequately perceive this threat.

The estimated economic and social loss for the country caused by the Chernobyl catastrophe is 235 billion USD ( 32 annual Belarusian budgets). However, during the last 10 years Belarus was only able to allocate 1,5 annual budgets for mitigating negative impacts of the catastrophe. Activities aimed at reducing the level of contamination are considered ineffective due to the negative influence of many other factors (bad air and water quality, social stress of the population, economic problems and poverty). The Chernobyl catastrophe put the Belarusian nation at the edge of a "struggle for survival":

- since 1987 , birth rate has fallen by $50 \%$ while mortality rate has increased by $32.7 \%$;

- in 2001 the mortality rate was 2 times higher than the fertility rate;

- the children's share of the population has been reduced from $28.9 \%$ to

$17.5 \%$ while the share of old people has increased to $19.2 \%$;

- almost half a million of the population emigrated while around

850000 migrated within the country;

- genetic deviations and cancer have grown noticeably. 
The consequences of the Chernobyl catastrophe demonstrate to all countries a need to take common responsibility for the sake of common security.

Finally, in the chapter certain aspects of institutional gaps in providing for the effective monitoring, prevention and minimisation of ecological threats in Belarus are described. In the process of social transformation and transition, the institutional sphere in Belarus is not able to react adequately or in-time to contradictions in various societal fields producing ecological threats. The key institutional factors of ecological threats remain as follows:

- weak information supply for decision-making due to the crisis in environmental data collection and scientific analysis;

- inadequate perception of ecological threats and low public participation in decision-making;

- lack of legal mechanisms for management of ecological threats and maintenance of national security;

- discrepancies between the control and management systems in the field of resource exploitation and protection of the environment, and the need for mitigation and prevention of ecological threats.

After the collapse of the USSR, Belarus has received a difficult ecological heritage: irrational resource exploitation, imperfect technologies, low levels of ecological culture, and the underdeveloped normative basis for the prevention and mitigation of ecological threats. The country's inability to solve new and old contradictions in the economic and social sphere using the old institutional mechanisms, deepens its national ecological threats and creates a challenge not only to the national but to regional ecological security, undermining the country's ability for sustainable development and keeping it from developing a legitimate national ecological security agenda.

\section{Relations with EU}

As a result of Lukashenko's management, Belarus has not been able to reap the benefits of its favourable geographical location (at the crossroads between the EU and Russia). Because of the unreformed Soviet-style economy and autocratic rule, Belarus does not attract foreign investors, it severely obstructs local entrepreneurs and it has a sharp budget deficit. The support from the Kremlin enabled the regime in Minsk to provide its citizens with cheap basic services. It has allowed the Belarusian economy to survive, and has enabled Minsk to continuously cancel the restructuring and implementation of potentially unpopular market reforms. One of the most important 'gifts' of Yeltsin were the gas supplies at a preferential rate.

However, since the presidency of Vladimir Putin the relationship with Moscow has changed and has become more businesslike. To the dismay of Lukashenko, the future Union (as agreed by Yeltsin and Lukashenko) between Belarus and Russia has become irrelevant. Putin's priority is to restore the power and influence of Russia. One of the most dramatic consequences of the changing rules by the Kremlin is 
that Belarus may lose its preferential treatment. The result of Putin's pragmatic stance is that Russia's influence is now extending towards every sphere in Belarus. Without Russia's support, Belarus is in desperate need of foreign investments, and its leadership is showing signs of despair.

Putin's political support for Lukashenko is going to be very costly for the latter. The regime will only get support from the Kremlin if it offers something interesting, i.e. the state companies which still need to be privatised. But without these companies Lukashenko will lose his relative independence from Moscow, and become a puppet. In reaction, Lukashenko changed his approach towards the Kremlin. He is sometimes stating his preference for integration with Russia, and at other times furiously objecting to it, arguing that Belarus will lose its sovereignty. The same tactics have been used in the failed privatisation scheme of the country's petrochemical sector, which was only open to Russian investors. It was obvious that investors could only be successful if they struck a deal with Lukashenko himself, i.e. if they would assist him in holding on to power. However, Russian investors were of the opinion that the price was too high. Moreover, they did not trust Lukashenko based on his notorious disrespect for contract obligations.

Belarus cannot maintain its reliance on a single country, even when it is Russia. Officially, the EU only comes in third place, with respect to Belarusian foreign policy priorities, but the reality shows that the $\mathrm{EU}$ is the principal trading partner of Minsk, with both imports from and exports to the EU growing each year. Therefore the EU cannot be neglected by Minsk, nor continued to be viewed as a hypocritical neighbour that wants to interfere in domestic politics (as stated by the government in Minsk). The political but especially the economic weight of the EU, the consequences of EU enlargement (such as the advancement of the 'Schengen wall' and the loss of trade and transport), the improving relationship between the EU and Russia, the worsening domestic socio-economic situation, and Putin's tough attitude towards Lukashenko will all force the leadership of Belarus to pay more attention to its western neighbours, and consequently, to play the game of the EU (e.g. democratisation, economic reforms, good governance). Lukashenko is becoming aware of his increasingly awkward position.

The approach of the EU towards Belarus is varied, which is mainly a result of the different directorates and pillars from which they are originating. First of all, there is the Tacis aid programme that assists the countries of the former Soviet Union. The second approach was only just created in March 2003 and is called 'Wider Europe - Neighbourhood: a New Framework for Relations with our Eastern and Southern Neighbours'. Next to these two inclusive approaches towards Belarus by the EU, through its CFSP instruments, there is a third approach that has developed within the Directorate-General for Justice and Home Affairs, which focuses on the establishment of an Area of Freedom, Security and Justice within the EU. The security strategy which was drafted in June 2003 by the cabinet of Javier Solana can be seen as a fourth approach of the EU towards its future neighbours. Officially the strategy falls under the rubric of CFSP, but it essentially mixes the tendencies put forward under the EU's internal and external policies. The document gives an analysis of the new threats the EU might be facing within the foreseeable future: terrorism, proliferation of weapons of mass destruction, weak states and organised crime. 
These four different EU approaches have a profound effect on the policies of Brussels: they are inclusive as well as exclusive. On the one hand, the EU wants to engage Belarus and to maximise the so-called economic challenges of enlargement, while on the other hand it wants to construct a strong external EU border that minimises the security risks posed by the unstable countries at the edge of the EU. This second approach will probably better cope with the security challenges posed by Lukashenko's management of Belarus.

The struggle for power. As a result of ten years of presidency, Lukashenko has a total grip on the state structures. He commands institutions and officials in Soviet style, and has direct and strict control over law enforcement, intelligence agencies and the justice system. His closest associates are directing them. In his treatment of top aides, Lukashenko acts as a classical despot: divide and rule. Continuously there is tension within the upper echelons of the regime, as different factions are fighting for influence. Lukashenko is handling former supporters who have become adversaries quite differently: he orders the public prosecutor to conduct criminal investigations. In addition to the harassment of former supporters, the regime is very consequential in its prosecution of opposition politicians and media.

Nevertheless, despite the enormous security apparatus, Belarusian law enforcement structures are unable to implement the rule of law. As a result - and because the border with Russia is porous - illegal migration, human trafficking and drug trafficking are considered to be an enormous problem since Belarus is an important transit country. In addition, it is highly probable that Belarusian border guards profit from the trafficking in illegal goods since their wages are extremely low. According to a public opinion poll held in October 2002, respondents stated that corruption occurs as a result of ineffective legislation, low salaries of functionaries and an absence of state control. The most corrupted are the state authorities, police, customs and local authorities. The measures against corruption are estimated as low or very low. Due to the ineffective law enforcement and the corruption, the EU will face a troubled border with Belarus.

There are even indications that the regime willingly co-operates with criminal gangs, as well as elements within law enforcement structures committing criminal acts that are ordered by their superiors. The most shocking example is the state of affairs around the disappearance of Zakharenko, Gonchar, Krasovsky and Zavadsky. The authorities have not shown any commitment to solve these disappearances. Two KGB agents who had to investigate the disappearances have shown that the abductions were ordered from above and conducted by a unit that was formed upon an order of Lukashenko. The gang was composed of members of the military elite Almaz-unit. It is alleged that members of Almaz have fought in Chechnya as mercenaries on the Chechen side, and have acted as intermediaries in the delivery of secretly supplied arms from Belarus to Chechen rebels via Turkey and Georgia. The arms supplies are alleged to have been co-ordinated by the then head of the Security Council of Belarus, Victor Sheiman.

There were around ten persons in this 'death squad', some of them convicted criminals or organised crime figures. The gang carried out about thirty murders. The gun that was used for the killings was the one that is used on death row, i.e. a gun that is impossible to identify as it is not registered in any database. The gun was handed 
over to the gang for a day or two and returned after the execution of an order. The group was so convinced of its impunity that it conducted several other criminal acts such as armed robberies and murders. The leader of the 'death squad,' Pavlichenko, was arrested on 21 November 2000 upon the order of Prosecutor General Oleg Bozhelko and KGB chief Vladimir Matskevich. Bozhelko sent a plea to his Russian counterpart Ustinov to provide machinery and specialists to conduct the investigation. A few days later Lukashenko dismissed Bozhelko, Matskevich and the Minister of Culture and released Pavlichenko with a public apology for his arrest. Ustinov was sent a letter that there was no need for the required help. Victor Sheiman, the man who was identified by the investigators as the link between Lukashenko and the 'death squad,' was appointed as the new Prosecutor General. Investigators and prosecutors who found evidence of the regime's involvement have fled the country, after one detective unexpectedly passed away and another was killed.

The struggle for money. In order to maintain the political support from a majority of the electorate the government needs to continue its generous social welfare system for the population and to pay salaries and pensions on time. But now that the government is running out of financial means, it has to abandon this policy (or risk bankruptcy). The consequence will be that the public (i.e. electorate) will become more critical of Lukashenko and that he will lose support. Lukashenko's reaction is reactive: the problems are caused by others. Within the public sector it is caused by either incapable or corrupt officials. Within the private sector it is caused by entrepreneurs who manipulate the market. As a result, and to keep up his image of integrity and honesty (and in order to get rid of non-obeying businessmen, opposition politicians and media), a new fight against corruption and 'theft from the state' was started.

The regime, however, has found a way out: it is selling weapons to countries that fall under international arms embargoes. The US government has repeatedly stated that it possesses evidence of Belarus' illegal arms deals. These are conducted through fake companies in Jordan and Syria, from where the weapons are transported to Iraq (and often paid back with oil). The payment scheme is as follows: a buyer transfers the money to an offshore account, from which it is transferred to fake companies in various countries, which then purchase arms from the manufacturers and transfer the money to their accounts. Another curious thing is that although Belarus has for several years been among the world's top ten leading arms exporters, it does not have a competitive or high-tech arms industry, and therefore the country can hardly sell its weapons on the international arms market. Lukashenko says that the only weapons that are sold are the leftovers from the Soviet period. However, according to leading opposition politicians, US officials and weapons experts, Belarus has long exhausted its Soviet reserves and now acts as an intermediary for Russian arms exports. Belarus eagerly ships arms to Algeria, Angola, Iran, Morocco, the Palestinian authorities, Sudan and, until recently, Afghanistan, Iraq, the Kosovo Liberation Army and Yugoslavia, always with the use of mediators.

Lukashenko himself has also been implicated in dubious financial deals. The Minister of Finance has declared that the president keeps an account on the 'Belarusbank', where funds are stored which were earned through the sale of 'special materials of the Ministry of Defence'. The Minister said that these funds are accumulated on the account as a presidential 'reserve fund' and 'stabilisation fund' for ensuring the relia- 
bility of the population's hard currency deposits. He admitted that the funds are not mentioned in any of the budget provisions. In other words, the President has the access to funds which are not accounted for and which have an estimated worth of 1 billion dollars. A few months earlier, in August 2001, the former Belarusian ambassador to Latvia, Estonia and Finland (who was recalled from his post after announcing his own political aspirations) said that Lukashenko himself had brokered arms deals with Chechnya.

Belarus poses no immediate threat to the EU. However, the country acquires more importance after enlargement since it will have a direct border. Due to its location, Belarus is vulnerable to illegal trafficking and organised crime. Belarus is a cross-road for a variety of transit routes. In addition, the customs union with Russia eliminated the internal borders with Russia, and there are no control points for illegal trafficking. Therefore, EU programmes directed at demarcation and overall strengthening of borders have become a priority for the EU. They have not been frozen, despite profound dissatisfaction about the current regime.

On the other hand, Lukashenko is posing an indirect threat to the EU. His domestic and international behaviour give rise to great concern. His closest associates have ordered the formation of a special team to liquidate political opponents and a journalist. Members of this team have fought in Chechnya and have probably acted as intermediaries in the sale of weapons from Belarus to Chechen fighters. Members of this team have committed other criminal acts, but are visited by the Minister of Interior while being detained. Promising leads in the investigations into the disappearances of political opponents have been stopped by Lukashenko himself.

Due to his international isolation, Lukashenko is looking for ways to earn money. He has established co-operation with countries in the Middle East and Africa. The reality is that he makes arms deals with notorious countries through fake companies and other countries. The threat that Belarus poses is not caused by internal instability or the prosperity gap. It is only caused by the President himself, who will do anything in order to hold on to power. He will make deals with criminals or terrorists, in order to liquidate opponents or to get the financial resources he needs to maintain control.

Lukashenko has become a victim of his own authoritarian and isolationist behaviour. Belarus' leadership cannot maintain its current policy for long. The electorate might currently be divided into urban and rural categories, and into liberals and conservatives; but this division will lose its relevance when the socio-economic crisis widens, deepens and hardens. Then the public will again make a practical assessment and not necessarily back Lukashenko. As a result, Lukashenko has to make changes in the way he governs the country, in order to stay afloat. The only sustainable way to do so is to introduce political and economic reforms. This has two implications for Belarus policy: re-assess its relationship with Russia and with the EU. For the very first time the conditional approach of the EU might be the right instrument.

The EU can play a very relevant role to support democratic changes in Bela- 
rus. It would not only benefit the region; the EU also owes it to itself to secure good, friendly relationships with all new neighbours. Brussels should at least try to establish such a relationship with Belarus, instead of remaining oblivious and only focusing on the way Lukashenko rules Belarus. The recently adopted Wider Europe Neighbourhood initiative addresses some of the concerns that resulted out of the conflicting arrangements for applicant countries: on the one hand Brussels is promoting regional cross-border co-operation but at the same time it is setting strict internal security policies preventing the development of the former. The new initiative is a more refined approach, attempting to synchronise the external and internal policies and connecting its three pillars, to enable an effective and manageable policy towards Belarus. The Wider Europe - Neighbourhood initiative is a welcome step in the right direction, dealing better with the diversity in political, economic and security interests of the enlarged Union, but it needs to contain concrete elements.

With a flexible approach, based on the conditionality that is already known to Lukashenko, the EU can have a more long term impact. Such a strategy would provide the society of Belarus with many incentives and opportunities for sustainable development in the longer term. But that is all that the EU can do. The greatest question is whether Lukashenko is willing to make changes that will cost him his current power and influence. Unfortunately, history has no examples of dictators that have spontaneously introduced changes at their own cost.

\section{Conclusions}

The main goal of this research was to enrich and make pithier the evaluation of Belarus as a regional security factor. As was already mentioned, this goal has been raised because Belarus, as a rule, is reduced to a Russian factor by the researchers of European or regional security and thus absolutely disappears from their field of vision or, at best, it is mentioned only in the "margins" of the analyses as a factor of minor importance. A preponderance of such evaluations is absolutely understandable and justified bearing in mind that the researchers usually are concerned with the essential points and minor factors are just put aside. That is why we would like to stress once more the conventional approach of this book and that the consecutive conclusions which are presented are in no way were questioned and, furthermore, there was no attempt made to negate them. The essence of the project was to try, as much as possible, to be freed as much as possible from the limits of the traditional context of the analyses (i.e. primarily from the Russian factor) and to underline the peculiarities of Belarus' political system, security sector, economy, ecology, relations with EU and possible trends in their development. At the same time, one more step was made to more widely clarify such atypical consequences of the country's political choices.

The main conclusion of this research is that the most important characteristics of Belarus as a regional security factor are defined by the choice of the country's principal political authorities to orient the development of the country to the Restoration of the soviet system with all of the related consequences. But bearing in mind that full restoration of the former state system is impossible due to the altered politi- 
cal, economic and ideological circumstances, the real situation is such that in present Belarus two structures, two worlds seem to live together. On the one hand, there are relics of the soviet system supported and constantly reanimated by the authorities. On the other hand - elements shaped by new times that cannot be isolated and ignored, with which the present political authorities are forced to reckon.

So, with a more attentive look at the Belarus political system in this research, we noticed that on the one hand the soviet ruling system is obviously repeated there. But on the other hand, we see some elements that are alien to it - such as NGOs, independent mass media, and minimal parliamentary opposition. Authorities are permanently fighting with them, strictly restricting them and even brutally attempting, without success, to eradicate them completely for a variety of reasons. Finally, the biggest, and perhaps the most destructive, problem of Belarusian Power Vertical which especially clearly differentiates it from the peculiarly "perfect" soviet power system is an ideological vacuum. Although, as we can see from the research, Lukashenko and his supporters understand this problem absolutely clearly and take all possible measures to solve it, the results are deplorable. Separated from the Power Vertical restoration, the restoration of the communist ideology that is of vital importance to the system is impossible in the present day period of information and communication, which is why, little by little, a national state ideology is forming.

It is no wonder that we see the signs of structural junctions peculiar to the Belarusian political system which affect the security sector as well. The research reveals that the soviet rudiment is preserved especially strongly in the main defence policy institutions of the country and in the documents defining its strategy. But despite this fact, the research has revealed the tendencies demonstrating inconsistency, incompleteness and non-perceptiveness of the Restoration. First of all, despite declared enthusiasm or real progress, the military integration of Belarus and Russia faces serious financial and even political barriers. Secondly, the one-way orientation of Belarus towards union with Russia does not move it away from NATO and puts all of Lukashenka's Restoration project in an embarrassing situation. Finally, despite how "pro-soviet" the Belarus authorities are, they cannot completely ignore the objective differences of state interests between Belarus and Russia as separate sovereign states dealing with security issues.

While it is possible to mask the two-faced situation in the security sector by propaganda measures, the economic situation can be plainly seen. On the one hand, the results of the study show that the state planned economy is preserved in full volume in modern Belarus and today it even functions rather successfully. While it is obvious that this type of economic system can be formed and can exist only with huge support from outside, which Russia continues to offer. On the other hand, the results of the research show that although such an economic system can be stable and experience average growth for quite a long period of time, quality problems will eventually accumulate (for example, the inability of state enterprises to invest in their own development and technological renovation) and for the time being, it will cause a slow down in the rate of growth and an eventual decline due to the disappearance of competition and all of its related social consequences.

Unfortunately, the analysis of the threats to the environment that exist in or originate from Belarus is cause for an even more pessimistic conclusion. There is a 
soviet heritage in this area distinguished principally by ecological nihilism in the literal sense of the word. Inherited soviet traditions of collecting and analysing environmental quality data allow neither precise evaluation of the real degree of Belarus ecosystems degradation nor the level of anthropogenic influence and thus fail to present the true scale of the ecological threat. But even the available data is descriptive enough, as clearly seen in the corresponding part of this study.

Finally, the „success" of the restoration implemented by Lukashenka is demonstrated by the state of relations with the European Union. The response of the EU to the dominating dictatorship and the suspension of market economy reforms in Belarus, was limited, suspended or terminated relations with the regime. The technical or other support provided earlier has been reduced to a minimum and re-oriented only to supporting the development of a civil society. For some time, the president of Belarus and his closest supporters were even prohibited from visiting EU countries. All measures of this type of sanctions were based on the assumption that the regime, facing such a critical rebuke, would try to normalize relations and thus would be forced to reform. But as the practice shows, the European Union won just a little from such a policy and in a sense it has voluntary been removed from the "game" and lost any real influence upon the processes taking place in Belarus.

At the same time, the results of the study show that there are more than enough reasons for the European Union to reconsider its rather strict position. Firstly, after EU enlargement, Belarus has become an immediate EU neighbour with hundreds of kilometres of shared borders that are impossible to protect without effective collaboration. Secondly, although Belarus itself does not pose a direct military threat to the $\mathrm{EU}$ and its member-states, the processes taking place there (political opponents being dealt with physically, the illegal trade of weapons, the danger of social explosion and mass migration, the gap in the level of economic welfare between EU and Belarus increasing more and more, an out of control ecological crisis) raise very acute questions about the future attitude of the European Union. Although it is known that the EU is planning the large programme Wider Europe - Neighbourhood to develop relations with close neighbours, it must be kept in mind that its implementation is related to the conditions imposed by the European Union of observing the basic principles of democracy and conducting market economy reforms. Thus, the circle seems closed. And there is no clear, concrete alternative.

But the results of this study stimulate the realization that in this case we face not the problem of Belarus only, but the broader one that can be defined as the problem of interrelations between democracy and dictatorship. Here we immediately note that there are no ready-made solutions. However, interrelations of democratic states with dictatorships are not limited to the formulation of demands and limiting relations when they are disobedient. The spectrum of possibilities is much wider. World practice shows that these relations vary from the pragmatic decision of maintaining relatively normal business relations while being completely dissociated from the processes that take place inside dictatorships (for example, relations with China) to exceptional cases of military intervention when the goal is to overthrow dictators and supporting opposition forces that are trying to restore or to create democracy in a country (for example, Iraq). These examples and many others, among them the experience of the West's collaboration with the Soviet Union during the 
Cold War, show that a wide spectrum of possibilities for democratic states' actions are determined not only by the wish of their governments and societies to support democracy, but also by considerably more factors that can be very different based on the specific case. So, when going back to the case of Belarus, we must bear in mind that the former soviet system is partly restored and has deep roots there, this system is subsidized by Russia on a great scale and we have no grounds to believe that the president of Belarus is afraid of being isolated. Therefore, his principal political views would not change through isolation. Thus, the proposal that the European Union should acknowledge the present gloomy reality and free itself from its own rhetorical snare seems to be more rational. The essence of such a turn would be "Deideologization" of the EU views on Belarus and a transformation to emphatically pragmatic collaboration corresponding to EU interests. If Belarus is such a peculiar anomaly - such a "mini Soviet Union" - we must remember the Cold War practices, when despite ideological opposition, there was still collaboration between the West and the Soviet Union on many important issues.

Perhaps the isolation of Belarus and dissociation from its affairs were justified before, when the former EU-15 had no directs connection with Belarus. However, EU enlargement has essentially changed the situation and has become the essential factor stimulating the EU to revise its principles related to its Belarus policy. Finally, we must remember that only by stopping isolation, only by broadening pragmatic, "deideologized" collaboration, is it possible to hope that the structure of the new political and economic system that now is just in a subordinate embryonic state would receive more space to express itself and to grow stronger. Such developments may clearly demonstrate to the Belarusian voters the possibilities and opportunities provided by supporting the return of democracy and observation of human rights. 